\title{
Towards a Decolonial Language Teacher Education
}

\section{Por uma Formação Decolonial de Professoras/es de Línguas}

Julma Dalva Vilarinho Pereira Borelli*

* Universidade Federal de Rondonópolis (UFR), Rondonópolis, Mato Grosso / Brasil julmaborelli@gmail.com

https://orcid.org/0000-0002-9456-8531

Viviane Pires Viana Silvestre**

** Universidade Estadual de Goiás (UEG), Anápolis, Goiás / Brasil

vivianepvs@gmail.com

https://orcid.org/0000-0003-2234-9046

Rosane Rocha Pessoa***

*** Universidade Federal de Goiás (UFG), Goiânia, Goiás / Brasil

pessoarosane@gmail.com

https://orcid.org/0000-0002-0538-2891

\begin{abstract}
In this article, we discuss the challenges of teacher education for the $21^{\text {st }}$ Century, taking decoloniality as a possible way to resignify our praxis. One of the challenges in decolonial thinking is to problematize the coloniality of knowledge (LANDER, 2005), which is established through the privilege of scientific knowledge and the invisibilization of other forms of knowing. In this respect, Castro-Gomez (2007) affirms that the university is an institution that contributes significantly to the maintenance of this logic. As university teachers directly involved in language teacher education, we have sought different ways to develop our praxis as a decolonial project (WALSH, 2013). In this article, we discuss decoloniality and present three praxes in which our objective was attempting to live language teacher education otherwise.
\end{abstract}

KEYWORDS: decoloniality; language teacher education; decolonial praxis.

RESUMO: Neste artigo, discutimos os desafios da formação docente para o século XXI, assumindo a decolonialidade como possibilidade de ressignificação de nossa práxis. Um dos desafios do pensamento decolonial é problematizar a colonialidade do saber (LANDER, 2005), que se estabelece por meio do privilégio do conhecimento científico e da invisibilização de outras formas de conhecer. A esse respeito, Castro-Gomez (2007) afirma que a universidade é uma instituição que contribui significativamente para a manutenção dessa 
ordem. Como professoras universitárias envolvidas diretamente com a formação de professoras/es de línguas, temos buscado diferentes formas de desenvolver nossa práxis como um projeto decolonial (WALSH, 2013). Neste artigo, discutimos a decolonialidade e apresentamos três práxis em que nosso objetivo foi tentar viver a formação de professoras/es de línguas de outro modo.

PALAVRAS-CHAVE: decolonialidade; formação de professoras/es de línguas; práxis decolonial.

My philosophical conviction is that we did not come to keep the world as it is; we came to the world in order to remake the world. We have to change reality.

Paulo Freire (1996)

\section{Living teacher education otherwise}

Added to old predicaments like the low status of the teaching profession, poor school infrastructure, class size, and low salaries, new demands of the early $21^{\text {st }}$ Century have challenged Brazilian teachers and teacher educators, such as teaching digital natives, dealing with students with special needs, handling time, and keeping good mental health. These demands have become even more challenging after Jair Bolsonaro was elected president, since funding to public education has been cut, Human and Social Sciences have been threatened, the phonic method has been defended as the solution to eradicate illiteracy, consolidated teacher education programs have been extinguished, and there has been an attempt to silence teachers' voices and to deny academic freedom.

Hence, understanding the principles that underlie our praxis and reflecting on the interests we are serving, that is, recognizing our praxis as political, are important commitments for those involved in language teacher education nowadays. However, aiming for a better understanding of the constructs that underpin the organization of our lives, as well as our praxis, may not be enough. Pennycook (2018, p. 102, emphasis in original) states:

As Foucault (1984a) argued, it becomes indispensable at a certain point in life to try to think otherwise - penser autrement - or, as Kearney (1988, 364) puts it, to take up "the ethical demand to imagine otherwise", if we want to continue to think and reflect usefully. If philosophy is to do anything other than continue to rethink the already thought, we have to ask how and how far we can start to think otherwise. 
Paraphrasing the author's argument, we aim to defend in this paper that, if language teacher education is to do anything other than continue to redo the already done, we have to ask how and how far we can start to live it otherwise.

By looking for alternative ways to live language teacher education otherwise, our research group - composed of (English) language teachers and language teachers educators from different educational contexts of the Midwest of Brazil, mainly the State of Goiás - have found in decolonial thinking (CASTRO-GÓMEZ, 2007; GROSFOGUEL, 2010; LANDER, 2005; MALDONADO-TORRES, 2007, 2010; MIGNOLO, 2009, 2012; QUIJANO, 2010) possibilities for the resignification of our praxis. ${ }^{1}$ We consider that decoloniality forces us to recognize that our praxis is still guided by remnants of a colonial power structure, historically instituted in our lives and socially reproduced in different spheres.

In order to undertake this challenge, we resort to Mignolo (2012), who emphasizes that to think about life and social organization from a decolonial perspective, we must first recognize that, "[f] or five hundred years, universal history was told from the perspective of one local history, that of Western civilization, an aberration, indeed, that passed for the truth" (MIGNOLO, 2012, p. ix). Corroborating this proposal, Lincoln and Canella (2007, p. 78) add: "Although the decolonial component would revision the oppressive stance of research as construct, the egalitarian component would go beyond countering domination, to construct unthought ways of being".

In our view, confronting the logic of coloniality that prevails in language teacher education domains requires the openness to create "yet unthought" alternatives. Grounded on decolonial perspectives, some alternatives seem to come to the fore: thinking and acting locally, decentering knowledge production and validation, emphasizing affection, relations and subjectivities, cherishing community, plurality and collaboration, submitting

\footnotetext{
${ }^{1}$ In 2015, we joined the Projeto Nacional de Letramentos: Linguagem Cultura, Educação e Tecnologia [National Project on Literacies: Language, Culture, Education and Technology], led by W. Monte Mor and L. M. T. Menezes de Souza from University of São Paulo (USP), and registered in the CNPq (National Council for Scientific and Technological Development) Research Groups Directory. Linked to this national project is the Rede Cerrado de Formação Crítica de Professoras/ es de Linguas [Cerrado Network of Critical Language Teacher Education], the research group in our region.
} 
to other worldviews etc. As Walsh, Oliveira and Candau (2018, p. 6) put it, the meaning of a decolonial pedagogy " $[. .$.$] is forged in the perspective of$ intervening in the reinvention of society, in the politicization of pedagogical action, proposing to unlearn what has been learned and to challenge the epistemic structures of coloniality." 2

Thus, we present a brief discussion about coloniality and the decolonial challenge (BORELLI, 2018). By doing this, we begin the process of perceiving ourselves immersed in a logic that needs and can be redefined. We then go on to discuss three different praxes, undertaken by each of the authors, which have constituted our decolonial efforts (SILVESTRE, 2016) to fight coloniality. We conclude by arguing for a decolonial language teacher education.

\section{Reflections on coloniality and the decolonial challenge}

We begin by distinguishing the difference between coloniality and colonialism. In the second half of the $20^{\text {th }}$ Century, many countries that were still under domination and exploitation by other countries won their independence (BALLESTRIN, 2013). This independence represented the end of colonialism, but coloniality remained. In this sense, coloniality refers to the establishment of a "colonial matrix of power" (GROSFOGUEL, 2010 , p. 467) that continues to be reproduced even in the absence of colonial administrations; that is, "we have come out of a period of 'global colonialism' to enter a period of 'global coloniality" (GROSFOGUEL, 2010, p. 467, emphasis in original).

Regarding this logic established with colonialism, Lander (2005, p. 10) argues that,

by constructing the notion of universality from the particular (or parochial) experience of European history and interpreting the totality of the time and space of human experience from the point of view of this particularity, a radically excluding universality is instituted.

In the same vein, Grosfoguel (2010, p. 464) points out that not only the notions of European epistemology, but also of sexuality and spirituality, were imposed on the rest of the world and became the basis for "racializing, classifying and pathologizing" beings, considering non-Europeans as lower

${ }^{2}$ The excerpts originally in Portuguese or Spanish were translated into English by us. 
races. This colonial matrix of power operates in different dimensions of society and is mainly maintained due to the difficulty we have to perceive ourselves as immersed in this logic and, consequently, to think of alternatives that may transgress the imposed and naturalized order. For Quijano (2010, p. 84),

coloniality is one of the constituent and specific elements of the world pattern of capitalist power. It is based on the imposition of a racial/ ethnic classification of the world's population as the cornerstone of the aforementioned power pattern and operates in each of the material and subjective domains, means and dimensions of everyday social existence and societal scale.

Based on this understanding, as well as on the recognition of injustices committed and suffering inflicted by different forms of coloniality, we can act in ways to challenge them. Although colonialities of knowledge (LANDER, 2005), being (MALDONADO-TORRES, 2007), and power (QUIJANO, 2005) operate together in our lives, in this paper, the coloniality of knowledge is emphasized, since it is more closely related to our discussions.

The coloniality of knowledge is maintained by the establishment of a logic and by impositions that exclude non-hegemonic forms of knowledge. Thus, a binarism is established between the scientific and the magical/ mythical. As Lander (2005) points out, the separation is an important constitutive dimension of the knowledge produced in modernity. Taking this discussion to the context of language teacher education, it is important to reflect on the types of knowledge we privilege in our lessons.

When we deal with epistemologies, the parameters established by Eurocentric rational science - universality, neutrality, and objectivity have, since the establishment of the colonial/modern period, defined and validated what could be considered knowledge. Along with this, there was an intense process of exclusion and erasure of other forms of knowledge, as well as other ways of knowing:

By breaking the link between the subject of enunciation and the ethnic/ $\mathrm{racial} / \mathrm{sexual} /$ gender/epistemic place, Western philosophy and science manage to create a myth about a true universal knowledge that masks, that is, conceals not only the speaker but also the epistemic, geo and body-political place of the structures of colonial power/knowledge from which the subject speaks. (GROSFOGUEL, 2010, p. 459). 
Castro-Gómez (2007) names the modern/colonial epistemic model "hubris ${ }^{3}$ of the zero point" and explains that this zero point would be a privileged place of observation, distanced from the object. It is as if the scientist could look at the world from the outside. This privileged position would meet the criteria of objectivity and neutrality in the production of knowledge that should be disembodied. In this line of thought, MaldonadoTorres (2010, p. 398) adds:

It is my conviction that this kind of belief in impartiality tends ultimately to reproduce blindness, not about space as such, but about non-European modes of thinking and also about the production and reproduction of the colonial/imperial relationship.

With regard to the process of generating knowledge, both Lander (2005) and Castro-Gómez (2007) highlight the separations, the compartmentalization established when trying to understand something:

Only on the basis of these separations - the basis of a disembodied and decontextualized knowledge - this very particular type of knowledge, that claims to be de-subjectivated (that is, objective) and universal, is conceivable" (LANDER, 2005, p. 9).

Thus, we understand that these parameters were used to create and justify the superiority of scientific knowledge and, consequently, to reinforce the highest degree of development of the peoples who were able to produce it.

Emphasizing the traits of coloniality that still characterize the organization of universities, Castro-Gómez (2007) argues that the same compartmentalization that occurred with knowledge is reproduced by the university through its disciplinary organization: "The academic subjects materialize the idea that reality must be divided into fragments and that the certainty of knowledge is reached as we focus on the analysis of one of these parts, ignoring their connections with all the others" (CASTROGÓMEZ, 2007, p. 83, emphasis in original). The author also points out that this reproduction occurs not only in the academic subjects, but also in the

\footnotetext{
${ }^{3}$ From Greek origin, it means excessive pride, presumption, or arrogance (originally toward the gods).
} 
division of faculties, departments that separate teachers according to their knowledge.

As a way of challenging this epistemic model, decolonial thinking advocates a geo-body-politically localized knowledge, that is, in this perspective the place of knowledge production is as important as the person that produces it. According to Mignolo (2012, p. xiv, emphasis in original), "[g]eo- and body-politics created the conditions for many to delink, to escape from the iron cage of imperial 'absolute knowledge"'. This openness allows us not only to confront the supposed universality of hegemonic knowledge, but also to recognize its place of production and to question the interests it serves. In line with these principles, decolonial criticism aims to "transcend western epistemology and canon" (GROSFOGUEL, 2010, p. 455). As the author underscores, decolonial criticism is a "critique of Eurocentrism by silenced and subalternized knowledge" (p. 456).

Reflecting on decolonial thinking, Walsh (2013, p. 67) argues that "decoloniality is not a theory to follow, but a project to take". A common feature of the different manifestations of this thinking is the recognition of the need to change the paradigm if we intend to challenge the established logic. It is not enough to speak of the subalternized perspective if our discussions are based on the epistemologies of the north. It is also insufficient to generate knowledge by talking about the subordinate. These people's silenced and invisibilized voices need to be heard meaningfully in the construction of this knowledge, and their discussion depends on a southern epistemological basis (SOUSA SANTOS, 2010). In this respect, Mignolo (2009, p. 4, emphasis in original) states the following:

I have been supporting in the past those who maintain that it is not enough to change the content of the conversation, that it is of the essence to change the terms of the conversation. [...] As far as controversies and interpretations remain within the same rules of the game (terms of the conversation), the control of knowledge is not called into question. And in order to call into question the modern/colonial foundation of the control of knowledge, it is necessary to focus on the knower rather than on the known.

Changing the rules of the game includes rethinking who participates in this game and what roles they experience in its development. 
By focusing on the knower, as Mignolo (2009) proposes, we need to be attentive to what or who in fact represents subalternized knowledge. Grosfoguel (2010, p. 459) contributes to this discussion by claiming that

the fact that one is socially placed on the oppressed side of power relations does not automatically mean that he thinks epistemically from a subaltern epistemic place. Precisely, the success of the colonial/modern world system lies in bringing subjects socially situated on the oppressed side of colonial difference to think epistemically as those in dominant positions.

This makes us recognize that colonialities are beyond bodies with their phenotypic traits, their linguistic characteristics and their forms of constructing knowledge; colonialities operate in our minds, and this narrows our possibilities and silence, with or without our consent, our words. We learn from a very early age that some people naturally deserve privileges and others do not, and we live in accordance with what we are taught. Transgressing these limits is part of the decolonial challenge. According to Grosfoguel (2010), the subaltern epistemic perspectives, beyond the place where they are located, are characterized by generating some form of criticism against hegemonic knowledge.

\section{Decolonial language teacher education praxes}

Concerning the challenge to live language teacher education otherwise, we have taken into consideration Maldonado-Torres' (2010) argument that, in order to rethink and reconceptualize our praxis, other voices need to express themselves and to be heard. For the author, the critique of the colonial model requires new spaces and new agents for the production of knowledge: "Radical criticism should take on dialogic forms. It should also take a form of radical self-questioning and dialogue" (MALDONADO-TORRES, 2010, p. 437, emphasis added). Moreover, Maldonado-Torres (2007, p. 262, emphasis in original) adds that

[t] he Decolonial Turn is about making visible the invisible and about analyzing the mechanisms that produce such invisibility or distorted visibility in light of a large stock of ideas that must necessarily include the critical reflections of the 'invisible' people themselves. Indeed, one must recognize their intellectual production as thinking - not only as culture or ideology. 
We understand that schoolteachers - especially those in the public education network - and student teachers are often in a marginalized position in language teacher education settings, subservient to the legitimized knowledge of the university teachers ${ }^{4}$ and academic theorists. In the case of English teachers from public schools in Brazil, this asymmetric situation becomes even more evident due to some naturalized notions in the Brazilian society, such as: no one learns English in regular schools, just in language schools; English schoolteachers do not "master" the language they should teach; the English classroom is simply a place where language is learned and consensual dialogue is held etc. In that regard, Walsh (2013, p. 19) defines "decolonial pedagogies" as "insurgent practices that crack the modernity/ coloniality and make possible very different ways of being, thinking, knowing, feeling, existing and living-with". These pedagogies can be taken as "practices of unlearning the imposed and assumed (MALDONADOTORRES, 2013) and relearning to be (future) English language teachers" (SILVESTRE, 2016, p. 115, emphasis in the original) and educators, resisting to naturalized notions about English language teaching in regular schools.

Moreover, decoloniality enables us to destabilize the epistemic privilege (ANDREOTTI, 2013) given to academic knowledge in relation to teacher's knowledge, which opens up the possibility of an epistemic pluralism (SOUSA SANTOS, 2010). This movement demands that we learn to be "comfortable with the discomfort of the uncertainties of living the plurality of existence; and they call us to become inspired [...] by the new possibilities [...] that do not offer any pre-determined scripts or guarantees" (ANDREOTTI, 2013, p. q.). As stated by Andreotti, Ahenakew, and Cooper (2012, p. 235): "[s]uch epistemological pluralism should emphasize the gifts and limitations of every knowledge system [...] and open new possibilities for thinking, seeing, knowing, relating and being". Likewise, what is expected is not the inversion of the epistemic privilege from a given knowledge to another, "but the recognition of the insufficiency and limitation of all types of knowledge, since it always represents the ignorance of other knowledges" (SILVESTRE, 2016, p. 116-117).

\footnotetext{
${ }^{4}$ We have used the term "university teacher", instead of university professor, to emphasize that we are all teachers despite the context in which we work. Lined with Mignolo (2009, p. 4), we have argued that "it is important to change the terms of the conversation".
} 
In the attempt to build our praxis based on these principles, we have developed our lessons as well as our studies as part of this decolonial project. In this text we present three examples of what has constituted our decolonial efforts: the first author reviews a research conducted with university teachers, schoolteachers, and student teachers in which they problematize the teaching practicum; next, the second author reports on her research findings regarding the concept of spaces of speech in a collaborative language teacher education experience; lastly, the third author discusses her work in the English lessons at an undergraduate teacher education program focusing on students' subjectivities.

\subsection{Relationships developed during the teaching practicum}

Developing the teaching practicum ${ }^{5}$ as a decolonial project requires some considerations. One is the recognition that living and being in the world in a decolonial manner is, for most of us, a challenge. Another point is that our attempts are justified by our commitment to an engaged pedagogy (hooks, 1994) that may result in a reconfiguration of what we understand as knowledge and the way it is built in our society and, more particularly, in the university. Still in the face of challenges, from a decolonial standpoint, one of them consists in recognizing the university as an institution that strongly maintains colonialities through the epistemic privilege that is attributed to scientific knowledge (GROSFOGUEL, 2013).

Arguing that our teaching practicum could be experienced as a decolonial project, as part of my doctoral studies, I developed a qualitative research (DENZIN; LINCOLN, 2013) with 10 university teachers, 11 schoolteachers, and 40 student teachers, aiming to create opportunities for those who experience the teaching practicum to express their knowledge. The subjects were from public universities and public schools located in the Midwest of Brazil. In doing this research, I argued that reflection on a decolonial teaching practicum had to be based on the knowledge of those who experience this process.

\footnotetext{
${ }^{5}$ I use the term teaching practicum to refer to the academic subject undergraduate students have in the two final years of the course. This academic subject focuses on pedagogical discussions and includes students' participation in school activities. In Brazil, it is titled as Estágio Supervisionado.
} 
However, once I decided that the conversations about the teaching practicum would constitute the main way to construct knowledge in that research, I also took into account that the actions of such a study had to be in accordance with this decolonial project. I then began my reflections on how to decolonize our research and was inspired by Glesne (2007, p. 171, emphasis in original), who asserts that

[w] tend to believe that a purpose of qualitative inquiry is to help us understand a social phenomenon. The more I experience, the more I wonder if I can ever fully understand anything. Presumption and arrogance often accompany our claims to understanding, which are partial at best [...]. Perhaps we and those we do research with would be better served if a purpose were one of 'solidarity'.

Thus, this perspective of solidarity became a priority in the conversations I had with them. In fact, if I wanted to rethink my actions as a teacher educator responsible for the teaching practicum, I would need my partners' solidarity. And here I might say that those who accepted to take part in the research were really engaged in contributing to a better understanding of the relationships established during the teaching practicum.

Thinking about the construction of knowledge in an ethical and political basis, Christians (2013, p. 153) claims that "[d]ialogue is the key element in an emancipatory strategy that liberates rather than imprisons us in manipulation or antagonistic relationship". In the same line, Lincoln and Canella (2007) argue that research needs to be reconceptualized regarding its foundations, purposes, methods, and forms of interpretation.

Accordingly, dialogue became a keyword in the process of reflecting upon the relationships established during the teaching practicum. For about 10 months, I visited different schools and universities, talking to teachers. I was also allowed by four university teachers to enter their groups of student teachers and invite them to share their experiences with me. All these conversations were recorded and problematized during the development of the study (BORELLI, 2018).

Considering that the teaching practicum involves universities and schools, my interest was to discuss the relationships between student teachers and university teachers, schoolteachers and student teachers, and university teachers and schoolteachers. I, therefore, asked them how they experienced these relationships during the teaching practicum. 
Focusing on the relationship between student teachers and university teachers, some student teachers mention that they would feel more secure if their university teachers participated more in the school activities. Sometimes they question if university teachers know what happens at school and the dynamics of this learning space. On the other hand, university teachers report that they have a good relationship with student teachers, but they stress the difficulties they face to work collaboratively with their colleagues. In summary, we see that difficulties in relationships do not involve necessarily a different context. This makes us consider that living otherwise in language teacher education contexts includes learning to work and learn together.

Concerning schoolteachers and student teachers, some schoolteachers report that they do not feel involved in the teaching practicum. Sometimes they interpret that student teachers need their classrooms to accomplish part of their teacher education process, but they do not seem to see this environment as a place where they can learn. Similarly, student teachers claim that they feel they are disturbed by the classroom routine and complain that, in some cases, the schoolteacher leaves them alone to deal with the students. In general, the reports show the lack of interaction in the development of a task that was meant to be collaborative.

As regards university teachers and schoolteachers, our conversations show that, most of the time, they do not know each other. In some cases, schoolteachers do not know what is expected from them and how they could help student teachers. On the other hand, university teachers state that some schoolteachers are not very open to participate.

The discussion of these relationships with this group of teachers shows the need to find new ways to integrate school and university subjects who are involved in the teaching practicum. It also contributes to the geo and body-political location of knowledge (MIGNOLO, 2012) by emphasizing the voices that constitute our discussions. Likewise, it reinforces the importance to question the privilege of scientific knowledge (CASTROGOMEZ, 2007), as it suggests that we should open ourselves to other ways of knowing. I consider that these local experiences can motivate teacher educators to rethink the types of relationship they develop during their teaching in general. In a decolonial project, we see that we are challenged to reconstruct these relationships collaboratively and in a more flattened way (SILVESTRE, 2016). 


\subsection{Spaces of speech in a collaborative language teacher education praxis}

The legacy of the colonialist project embedded in our identities makes us perpetuate markedly asymmetrical, top-down hierarchical power relations and knowledge building in our language teacher education work, even in the so-called collaborative praxis. In an attempt to problematize this logic of coloniality often reproduced in teacher education settings, in my doctoral research (SILVESTRE, 2016), I discussed the establishment of a possible dialogue between collaborative and decolonial perspectives, based on a language teacher education experience within PIBID (Programa Institucional de Bolsa de Iniciação à Docência [Institutional Scholarship Program for Initiation to Teaching]). The project was developed in partnership with a public junior high school, in the Midwest of Brazil, and included the participation of seven undergraduate students of a language teacher education program of a public university, a teacher from that university course (me), and the English teacher of the partner school.

Tuned with Walsh's (2013) concept of “decolonial pedagogies”, I advocate collaborative action in teacher education in a decolonial point of view as a praxis that shudders naturalized asymmetrical relationships mainly regarding the school and the university worlds - and opens up other possibilities of living-with in the process of language teacher education, in which insurgency of marginalized voices and knowledge is made possible. In this sense, collaboration - understood under a decolonial perspective - is defined as "a complex dialogue between agents who take part in the localized construction of knowledge about linguistic education, strongly marked by the act of listening to the different voices of this dialogical process of meaning making" (SILVESTRE, 2016, p. 121).

As we can infer from Maldonado-Torres' (2007, p. 261) arguments, any decolonial project is "an invitation to engage in dialogue". In this sense, if we bear in mind the need to integrate the different voices - that is, the different knowledges both hegemonic and marginalized - that compose language teacher education, it becomes urgent to foster the building of spaces of speech as a decolonial effort in language teacher education. Space of speech is conceptualized as "time and place of attentive listening and emergence of different knowledges in the construction of other knowledges based on a pluralistic and dialogical logic" (SILVESTRE, 2016, p. 183), in which language is seen as "a form of action in a specific place and time" 
(PENNYCOOK, 2010, p. 1). This concept is based on a plural logic of knowledge construction and validation, not denying the tensions that might arise in the process.

In that collaborative language teacher education praxis, the spaces of speech were mainly built during the weekly face-to-face group meetings (student teachers, schoolteacher, and university teacher), which we called "reflective sessions". 6 Those moments were marked by the questioning of our own perspectives, values, and truths - about ourselves and others -, which led to the (re)constructions of our praxis and meanings regarding not just language education, but also our subjectivities. In addition, the engagement in those spaces of speech seemed to nourish the sense of belonging to a (teacher) group, due to their reflective and transformative feature.

On the other hand, it is to be noted that the act of positioning oneself in a space of speech can also be a challenging process for some people. As Maldonado-Torres (2007, p. 261) points out, "concepts need to be conceived as invitations to dialogue and not as impositions. They are expressions of the availability of the subject to engage in dialogue and the desire for exchange". In this sense, the interpersonal relationships established in spaces of speech should be procedurally and non-linearly built in the collaborative action between the agents that integrate them. Likewise, tensions must be faced as part of the process rather than neglected.

Hence, Andreotti (2013, p. o) claims that "in order to learn to listen to, learn from and/or work with other peoples and knowledges, we would first need to learn to unlearn". Walsh (2018, p. 93) also argues that "learning to unlearn in order to relearn [is] a central component of decoloniality in/ as praxis".

Therefore, the results of the study pointed out that collaboration understood from a decolonial stance allows other alternatives for living language teacher education, which broadens the possibilities for resignifying relations among people and their knowledge often distanced by the logic of coloniality. In sum,

\footnotetext{
${ }^{6}$ Those meetings occurred in a room in the university campus, usually on Tuesday afternoons, and they usually lasted two hours each. In all, we had 52 reflective sessions along the nineteen months of the research development.
} 
thinking about language teacher education from a decolonial perspective implies decentralizing power, through flattened bierarchies, ${ }^{7}$ integrating teachers into the process of pedagogical (and political) decision making, enabling spaces of speech where teachers can speak their minds, listening to them with meaning, dialogizing with them, reporting their achievements, collaboratively problematizing their own practices and those of others so that they can exercise their teacher agency ${ }^{8}$ in accordance with what they desire and can best offer for their students' language education (SILVESTRE, 2016, p. 151, emphasis in original).

Thus, the decolonial lenses seem to be an option that can entail important destabilization to local teacher education praxis.

\subsection{Subjectivities in English lessons at a teacher education undergraduate program}

The logic of coloniality, discussed by Grosfoguel (2010), is manifested in many aspects of English teaching, starting from the fact that we teach a colonial language. We are aware that English is linked to inequality, injustice, and the prevention of communication; thus, as Pennycook (2018, p. 135) argues, it should be localized or "provincialized". By this, he means that we should acknowledge not only

its possible indispensability within current conditions of globalization, [...] but also its insufficiency for global communication, its perpetuation of inequalities, its destructiveness in relation to other languages and cultures. (PENNYCOOK, 2018, p. 135).

We are also aware that we can use our English to problematize discourses of oppression and promote discourses that favor plurality and localized knowledges. This is what I have been trying to do in my English lessons at a teacher education undergraduate program for more than ten years.

\footnotetext{
${ }^{7}$ Flattened bierarchy means "an attempt to destabilize markedly asymmetrical knowledge/ power relations, by decentralizing responsibilities and epistemic roles/places" (SILVESTRE, 2016, p. 183).

${ }^{8}$ Teacher agency can be defined as a "socioculturally built/shared attitude and acknowledgment of the teacher to act in his/her professional context” (SILVESTRE, 2016, p. 183).
} 
Since I started to reflect on language teaching more critically, I have questioned English language textbooks as most of them present very specific types of subjects, who normally come from capitalist countries, have a home and a nuclear family, have jobs, have time for leisure, have hobbies, go on holidays, and speak Standard English. According to Block (2017), such textbook topics show how neoliberalism has colonized different domains of social activity. In this vein, Lin (2013, p. 540) argues that communicative language teaching methodology is "intimately linked to the production of a certain kind of student and worker subjectivity suitable for participating in a certain kind of political economy". In my view, it is a clear example of how colonialities operate in language classrooms, as I consider that these topics strengthen colonialities in the sphere of economy, gender, sexuality, language, spirituality etc., ending up maintaining "dominant structures of knowledge and power" (WALSH, 2007, p. 26). However, as we have argued elsewhere (PESSOA, 2014; PESSOA; HOELZLE, 2017; PESSOA; BORELLI; SILVESTRE, 2018), there is much more to subjectivities than what is shown in the life of textbook characters and we consider they should be better explored, especially in university teacher education courses.

For a long time, I asked my students to introduce themselves in the first English lesson, and, in this activity, they normally said their names, described their personalities and talked about what they like doing. That changed when I introduced the discussion of identities, ${ }^{9}$ so instead of creating dialogues to give trivial information about ourselves, we read a short text about identity focusing on the following topics: the difference between personality and identity; the fact that taking up an identity involves some active engagement and requires an element of choice; our need to share identities with others by means of, for example, symbols and representations; the link between our identities and society; the constraints that limit the degree of agency we have in building our identities. Following this discussion, we study texts that focus on "the subaltern side of the colonial difference: the side of the periphery, of workers, of women, of racialized/ colonized individuals, of homosexuals/lesbians" (GROSFOGUEL, 2010, p. 479). This work has usually resulted in students positioning themselves in terms of their subjectivities.

${ }^{9}$ The terms identities and subjectivities are used interchangebly in this text. 
In the first semester of 2019, for instance, in the subject of English Oral Practice 1, ${ }^{10}$ we worked with the poem "I, Too", by Langston Hughes (1994), the film “The Help" (2012), the song "Ain't Got No, I Got Life", by Nina Simone (1968), the video "Don't Judge my African American English" (2015), and the text "Language" by bell hooks (1994). At the end of the first term, my students had to make five-minute speeches about themselves and five out of ten were very positioned speeches. A female student affirmed that she does not wear bras and that she does not agree with social norms regarding clothes. A second female student said she is feminist and added that she fights to be heard among her male family members. A third female student said that as she felt attracted to girls when she was young, she wished to represent herself as a boy because, by doing that, she would comply with her religious norms, according to which boys like girls and girls like boys. A male student said he has Asperger's syndrome, described the syndrome and ended up highlighting how difficult it was for him to talk about it in public as he was doing at that moment. Another male student said he was a guitar player and talked about his involvement in fights and a university lawsuit against him. Interesting enough, after the speeches, a student who had talked about her normal life seemed a bit disappointed because she had nothing relevant to say about her identity, implying that she had acknowledged the importance of being socially positioned.

Relevant in this praxis is the opportunity of realizing that voices other than the neoliberal characters represented in textbooks need to express themselves and be heard, as it has been mentioned before. One step further, on track with Maldonado-Torres (2007) and Andreotti (2013), is to examine why we do not always feel comfortable talking about our subaltern subjectivities and why it is simpler to make them invisible. Such activities may make student teachers better prepared to teach in the very diverse public schools we have in Brazil, as they are heterogeneous, rich spaces of knowledges and cultures that must be explored and delved into. By drawing our attention to students' diverse subjectivities, I believe we are creating conditions for different knowledges and lives, and I like to think of it as a decolonial effort. This aligns with Walsh (2013, p. 33) when she argues that, in order to "confront the hegemony and coloniality of Western thought, it is

\footnotetext{
${ }^{10}$ This academic subject is offered in the first semester of the four-year English teacher education undergraduate course titled Letras: Inglês.
} 
necessary to confront and make visible our own subjectivities and practices, including our pedagogical practices".

Decolonially speaking, I should also question why it is that I start my English language lessons by talking about our subjectivities. It is certainly because I was taught to say my name, address, telephone number, and my hometown at the beginning of all my language lessons (be it English, French, Spanish, Italian, or German) since this is the starting point of most language textbooks. However, I wonder if I should not expand my views and start off by talking about collectivities instead of subjectivities, or even take out humans from the center and explore the idea of vincularidad by some Andean Indigenous thinkers, which, according to Walsh and Mignolo (2018, p. 1), "[...] is the awareness of the integral relation and interdependence amongst all living organisms (in which humans are only a part) with territory and land and the cosmos". It would be a step further in the unlearning of what I have learned. After all, decoloniality is an invitation to a continuous redefinition and resignification of our pedagogical praxis and of our lives.

\section{Closings and openings}

Although we have chosen to discuss the three examples of our praxes - understood as our decolonial efforts to live language teacher education otherwise - in separate sections, we believe they are intertwined. Borelli's (2018) research has shown to be a space of speech for the ones directly involved in English teaching practicum, as has Pessoa's lessons for her student teachers of the undergraduate English teacher education course. In addition, agents' subjectivities and the relationship among them were key elements in Silvestre's (2016) studies well as in the lessons discussed by Pessoa. As Walsh (2018a, p. 50) reminds us, "[p]raxis, in a Freirian sense, is 'an act of knowing that involves a dialogical movement that goes from action to reflection and from reflection upon action to a new action' [FREIRE, 1985, p. 50]". It was not by chance that we have opened our text with Paulo Freire's (1996) words, encouraging us to notice that we have the power to change reality through our praxis. The importance of his thought is recognized by the decolonial scholar Walsh (2018b, p. 89):

Still, and despite Freire's limitations with regard to the modern/colonial matrix of power (something he himself began to recognize in his last years), much of his praxistical liberation-based thought remains relevant. 
This relevance is, in fact, the subject of attack by Latin America's recently emergent extreme Right, led largely by evangelical movements and transnational interests. Brazil is a case in point.

Considering the macro context of our country, especially concerning education and our work as university teachers, we could state that decoloniality, as a way to challenge inequality, silencing, and injustice, shows itself to be of great relevance in this scenario. We believe that, in order to deal with the challenges we face in language teacher education, we should not only build spaces of speech, where subjectivities, voices, knowledges, and bodies invisibilized/silenced by the colonial matrix of power can be heard and seen, and where relationships are strengthened; but also strive for collectiveness, plurality, and locality.

In this paper, we have argued for a decolonial language teacher education, which is to be built locally, and requires both ontological and epistemological moves in the area of Language Teacher Education in Brazil and elsewhere. Aligned with Kumaravadivelu (2012), we consider that language teacher education is to be rebuilt by local praxes. Furthermore, in order to face the decolonial challenge, we must dare to live language teacher education otherwise, which means accepting the challenge to resignify our praxis taking into account that it needs others to exist. Therefore, it has to be built together with others, considering their knowledges, voices, and subjectivities, and recognizing the power we gain when we work as a group willing to share.

On the other hand, Walsh, Oliveira and Candau (2018) warn us that any decolonial educational project should go beyond the narrow academic space and be constructed in dialogue not only with the various educational realities, but also with social, political movements, which constitute a different way of thinking/being/doing/feeling the praxis and rhetoric of modernity. This is another facet of the decolonial challenge that we university language educators - must dare to face in the remaining years of the mid- $21^{\text {st }}$ Century. 


\section{Acknowledgements}

We would like to thank Laryssa Paulino de Queiroz Sousa and Pedro Augusto de Lima Bastos for their very careful reading of the manuscript and the resulting constructive comments.

Rosane Rocha Pessoa thanks CNPq for the research productivity grant Level 2.

\section{Authors' contribution}

Sections 1, 2, 3, and 4 were written collaboratively by the three authors. Julma Borelli authored section 3.1, Viviane Silvestre authored section 3.2, and Rosane Pessoa authored section 3.3 individually.

\section{References}

ANDREOTTI, Vanessa; AHENAKEW, Cash; COOPER, Garrick. Equivocal knowing and elusive realities: imagining global citizenship otherwise. In: ANDREOT'TI, Vanessa; SOUZA, Lynn M. T. M. de (ed.). Postcolonial Perspectives on Global Citizenship Education. New York: Routledge, 2012. p. 221-237. DOI: https:// doi.org/10.1007/978-94-6300-277-6_18

ANDREOTTI, Vanessa; AHENAKEW, Cash; COOPER, Garrick. Equivocal knowing and elusive realities: imagining global citizenship otherwise. In: ANDREOTTI, Vanessa; SOUZA, Lynn M. T. M. de (ed.). Postcolonial Perspectives on Global Citizenship Education. New York: Routledge, 2012. p. 221-237.

ANDREOTTI, Vanessa O. Renegotiating Epistemic Privilege and Enchantments with Modernity: The Gain in the Loss of the Entitlement to Control and Define Everything. In: BROOM, Catherine; WISEMAN, Lynne (ed.). Social Policy, Education and Curriculum Research Unit. North Dartmouth: Centre For Policy Analyses/ UMassDartmouth, 2013. p. 6-18.

BALLESTRIN, Luciana. América Latina e o giro decolonial. Revista Brasileira de Ciência Política, Brasília, n. 11, p. 89-117. mai./ago. 2013. DOI: https://doi. org/10.1590/S0103-33522013000200004

BLOCK, David. Neoliberalism, the Neoliberal Citizen and English Language Teaching Materials: A Critical Analysis/Neoliberalismo, el ciudadano neoliberal y los materiales para la enseñanza de la lengua inglesa: un análisis crítico. Ruta Maestra, Bogotá, 21, p. 4-15, 2017. 
BORELLI, Julma D. V. P. O estágio e o desafio decolonial: (des)construindo sentidos sobre a formação de professores/as de inglês. 2018. 224f. Dissertation (Ph.D in Letters and Linguistics) - Faculdade de Letras, Universidade Federal de Goiás, Goiânia, 2018.

CASTRO-GÓMEZ, Santiago. Decolonizar la universidad: la hybris del punto cero y el diálogo de saberes. In: CASTRO-GÓMEZ, Santiago; GROFÓGUEL, Ramón. (org.). El giro decolonial: reflexiones para uma diversidad epistémica más allá del capitalismo global, Bogotá: Siglo del Hombre Editores, 2007. p. 79-91.

CHRISTIANS, Clifford G. Ethics and politics in qualitative research. In: DENZIN, Norman K.; LINCOLN, Yvonna S. (ed.). The Landscape of Qualitative Research. 4. ed. Thousand Oaks: Sage Publications, 2013. p. 125-167.

DENZIN, Norman K.; LINCOLN, Yvonna S. The Discipline and Practice of Qualitative Research. In: . (ed.) The Landscape of Qualitative Research. 4. ed. Thousand Oaks: Sage Publications, 2013. p. 1-41.

Don't Judge my African American English. In: Utube, Oct 30, 2015. Available at: https://www.youtube.com/watch?v=j7_rihFMB78. Retrieved on: 6 May 2019.

FOUCAULT, Michael. Histoire de la sexualité II: L'usage des plaisirs. Paris: Gallimard, 1984.

FREIRE, Paulo. An Incredible Conversation with Paulo Freire, 1996. Available at: https://www.youtube.com/watch?v=aFWjnkFypFA. Retrieved on: 24 April 2018.

GLESNE, Corrine. Research as solidarity. In: DENZIN, Norman K.; GIARDINA, Michael D. Ethical Futures in Qualitative Research. Walnut Creek: Left Coast Press, 2007. p. 169-178.

GROSFOGUEL, Ramón. Para descolonizar os estudos de economia política e os estudos pós-coloniais: transmodernidade, pensamento de fronteira e colonialidade global. In: SOUSA SANTOS, Boaventura; MENESES, Maria P. (org.). Epistemologias do sul. São Paulo: Cortez, 2010. p. 455-491. DOI: https://doi.org/10.12957/ periferia.2009.3428

GROSFOGUEL, Ramón. The Structure of Knowledge in Westernized Universities: Epistemic Racism/Sexism and the Four Genocides/Epistemicides of the Long $16^{\text {th }}$ Century. Human Architecture: Journal of the Sociology of Self-knowledge, [S.l.], v. 11, n. 1, p. 73-90, Fall, 2013.

HOOKS, Bell. Teaching to Transgress: Education as the Practice of Freedom. New York, Routledge, 1994. 
HUGHES, Langston. In: RAMPERSAD, Arnold; ROESSEL, David (ed.). The Collected Poems of Langston Hughes. New York: Knopf, 1994.

KEARNEY, Richard. The Wake of Imagination. Minneapolis: University of Minnesota Press, 1988.

KUMARAVADIVELU, Bala. Individual Identity, Cultural Globalization and Teaching English as an International Language: The Case for an Epistemic Break. In: ALSAGOFF, Lubna; RENANDYA, Willy A.; HU, Guangwei; MCKAY, Sandra L. (ed.). Teaching English as an International Language: Principles and Practices. New York: Routledge, 2012. p. 9-27.

LANDER, Edgardo. Ciências sociais: saberes coloniais e eurocêntricos. In:

(org.). A colonialidade do saber: eurocentrismo e ciências sociais. Buenos Aires: Conselho Latino-americano de Ciências Sociais - ClaCso, 2005. p. 8-20.

LIN, Angel. Toward Paradigmatic Change in TESOL Methodologies: Building Plurilingual Pedagogies from the Ground up. TESOL Quarterly, [S.l.], v. 47, n. 3, p. 521-545, 2013. DOI: https://doi.org/10.1002/tesq.113

LINCOLN, Yvonna S.; CANNELLA, Gaile S. Ethics and the Broader Rethinking/ Reconceptualization of Research as Construct. In: DENZIN, Norman K.; GIARDINA, Michael D. Ethical Futures in Qualitative Research. Walnut Creek: Left Coast Press, 2007. p. 67-84.

MALDONADO-TORRES, Nelson. 'On the Coloniality of Being' - Contributions to the Development of a Concept, Cultural Studies, [S.l.], v. 21, n. 2, p. 240- 270, 2007. DOI: https://doi.org/10.1080/09502380601162548

MALDONADO-TORRES, Nelson. A topologia do ser e a geopolítica do conhecimento: modernidade, império e colonialidade. In: SOUSA SANTOS, Boaventura; MENESES, Maria P. (org.). Epistemologias do sul. São Paulo: Cortez, 2010. p. 396-443.

MIGNOLO, Walter D. Epistemic Disobedience, Independent Thought and De-Colonial Freedom. Theory, Culture \& Society, Los Angeles, London, New Delhi, Singapore, v. 26, n. 7-8, p. 1-23, 2009. DOI: https://doi. org/10.1177/0263276409349275

MIGNOLO, Walter D. Local Histories/Global Designs: Coloniality, Subaltern Knowledges and Border Thinking. Princeton: Princeton University Press, 2012. DOI: https://doi.org/10.1515/9781400845064

PENNYCOOK, Alastair. Language as a Local Practice. New York: Routledge, 2010. DOI: https://doi.org/10.4324/9780203846223 
PENNYCOOK, Alastair. Posthumanist Applied Linguistics. Oxford; New York: Routledge, 2018. DOI: https://doi.org/10.4324/9781315457574

PESSOA, Rosane R. A Critical Approach to the Teaching of English: Pedagogical and Identity Engagement. Revista Brasileira de Linguistica Aplicada, Belo Horizonte, v. 14, n. 2, p. 353-372, 2014. DOI: https://doi.org/10.1590/S198463982014005000005

PESSOA, Rosane R.; HOELZLE, Maria José. Ensino de línguas como palco de política linguística: mobilização de repertórios sobre gênero. Trabalhos em Linguística Aplicada, Campinas, v. 56, n. 3, p. 782-800, set./dez. 2017. DOI: https://doi.org/ 10.1590/010318138649840291441

PESSOA, Rosane R.; BORELLI, Julma D. V. P.; SILVESTRE, Viviane P. V. "Speaking Properly": Language Conceptions Problematized in English Lessons of an Undergraduate Teacher Education Course in Brazil. Ilha do Desterro, Florianópolis, v. 71, n. 3, p. 81-98, set/dez 2018. DOI: https://doi. org/10.5007/2175-8026.2018v71n3p81

QUIJANO, Aníbal. Colonialidade do poder e classificação social. In: SOUSA SANTOS, Boaventura; MENESES, Maria P. (org.). Epistemologias do sul. São Paulo: Cortez, 2010. p. 84-130.

SIMONE, Nina. Ain't Got No, I Got Life. In: Nuff Said. New York City: RCA Studios, 1968.

SILVESTRE, Viviane P. V. Práticas problematizadoras e de(s)coloniais na formação de professores/as de línguas: teorizações construídas em uma experiência com o Pibid. 2016. 239f. Dissertation (Ph.D in Letters and Linguistics) - Universidade Federal de Goiás, Goiânia, 2016.

SOUSA SANTOS, Boaventura de. Para além do pensamento abissal: das linhas globais a uma ecologia de saberes. In: SOUSA SANTOS, Boaventura de; MENESES, Maria P. (Org.). Epistemologias do sul. São Paulo: Cortez, 2010. p. 32-83.

THE Help. Direção: Tate Taylor. Fotografia Stephen Goldblatt. [S.l.]: DreamWorks, 2012. 1 DVD (146 min.), NTST, color.

WALSH, Catherine. Interculturalidad, Colonialidad y Educación. Revista Educación y Pedagogía, Medellín, v. XIX, n. 48, p. 25-35, 2007.

WALSH, Catherine. Lo pedagógico y ló decolonial: entretejiendo caminos. In: . (org.) Pedagogías decoloniales: prácticas insurgentes de resistir, (re)existir y

(re)vivir. Quito: Abya Yala, 2013. p. 23-68. 
WALSH, Catherine. Insurgency and Decolonial Prospect, Praxis, and Project. In: MIGNOLO, Walter D.; WALSH, Catherine (ed.). On Decoloniality: Concepts, Analytics, Praxis. Durham: Duke University Press, 2018a. p. 33-56. DOI: https:/ / doi.org/10.1215/9780822371779-003

WALSH, Catherine. On Decolonial Dangers, Decolonial Cracks, and Decolonial Pedagogies Rising. In: MIGNOLO, Walter D.; WALSH, Catherine. On Decoloniality: Concepts, Analytics, Praxis. Durham: Duke University Press, 2018b. p. 81-98. DOI: https://doi.org/10.1215/9780822371779-005

WALSH, Catherine; MIGNOLO, Walter. Introduction. In: MIGNOLO, Walter D.; WALSH, Catherine. On Decoloniality: Concepts, Analytics, Praxis. Durham: Duke University Press, 2018. p. 1-12.

WALSH, Catherine; OLIVEIRA, Luiz Fernandes de; CANDAU, Vera Maria. Colonialidade e pedagogia decolonial: Para pensar uma educação outra. Arquivos Analíticos de Políticas educativas, [S.l.], v. 26, n. 8, p.1-16, 2018. DOI: https://doi. org/10.14507/epaa.26.3874

Data de submissão: 07/06/2019. Data de aprovação: 31/10/2019. 